\title{
Complement Receptor 2 Is Expressed in Neural Progenitor Cells and Regulates Adult Hippocampal Neurogenesis
}

\author{
Maiko Moriyama, ${ }^{1 \star}$ Takeshi Fukuhara, ${ }^{1 \star}$ Markus Britschgi, ${ }^{1}$ Yingbo He,${ }^{1}$ Ramya Narasimhan, ${ }^{1}$ Saul Villeda, ${ }^{1}$ \\ Hector Molina, ${ }^{2}$ Brigitte T. Huber, ${ }^{3}$ Mike Holers, ${ }^{4}$ and Tony Wyss-Coray ${ }^{1,5}$ \\ ${ }^{1}$ Department of Neurology and Neurological Sciences, Stanford University School of Medicine, Palo Alto, California 94305, ${ }^{2}$ Department of Medicine, \\ Washington University School of Medicine, St. Louis, Missouri 63110, ${ }^{3}$ Department of Pathology, Tufts University School of Medicine, Boston, \\ Massachusetts 02111, ${ }^{4}$ Departments of Medicine and Immunology, University of Colorado at Denver and Health Sciences Center, Aurora, Colorado 80045, \\ and ${ }^{5}$ Rehabilitation, Research, and Development, Veterans Administration Palo Alto Health Care System, Palo Alto, California 94305
}

Injury and inflammation are potent regulators of adult neurogenesis. As the complement system forms a key immune pathway that may also exert critical functions in neural development and neurodegeneration, we asked whether complement receptors regulate neurogenesis. We discovered that complement receptor 2 (CR2), classically known as a coreceptor of the B-lymphocyte antigen receptor, is expressed in adult neural progenitor cells (NPCs) of the dentate gyrus. Two of its ligands, C3d and interferon- $\alpha$ (IFN- $\alpha$ ), inhibited proliferation of wild-type NPCs but not NPCs derived from mice lacking $\mathrm{Cr} 2\left(\mathrm{Cr}^{-/-}\right)$, indicating functional $\mathrm{Cr} 2$ expression. Young and old $\mathrm{Cr} 2^{-1-}$ mice exhibited prominent increases in basal neurogenesis compared with wild-type littermates, whereas intracerebral injection of $\mathrm{C} 3 \mathrm{~d}$ resulted in fewer proliferating neuroblasts in wild-type than in $\mathrm{Cr} 2^{-/-}$mice. We conclude that $\mathrm{Cr} 2 \mathrm{regulates}$ hippocampal neurogenesis and propose that increased C3d and IFN- $\alpha$ production associated with brain injury or viral infections may inhibit neurogenesis.

\section{Introduction}

The complement system is an important regulator of immune responses. Complement proteins can attract and activate various immune cells, amplify adaptive immune responses, promote phagocytosis, facilitate complement-mediated cytolysis by the membrane attack complex, and regulate cell proliferation and differentiation. Complement C3 is the central protein of the complement cascade, mediating its functions through various proteolytic fragments that bind to distinct complement receptors (CR) (Holers, 1996; Sahu and Lambris, 2001). Different C3 fragments can bind to CR1 (also known as CD35), CR2 (CD21), CR3 (CD11b/CD18), CR4 (CD11c/CD18), as well as C3a receptor (C3aR) (Holers, 1996). Most of these receptors and their functions are conserved between mouse and human except CD35, which is an alternative splice product of the $\mathrm{Cr} 2$ gene in mouse but encoded by a separate gene in humans (Jacobson and Weis, 2008).

In the brain, complement can be produced by astrocytes, microglia, and neurons, and production is increased in brain injury and neurodegeneration (D'Ambrosio et al., 2001; Gasque, 2004).

Received July 12, 2010; revised Dec. 27, 2010; accepted Jan. 12, 2011.

This work was supported by a postdoctoral fellowship from the Japanese Society for Promotion of Sciences (M.M.) and by National Institute on Aging Grants AG20603 and AG27505 (T.W.-C.). We thank Dr. T. Palmer for the rat NPC line and advice on the culture and analysis of NPCs, Dr. M. Buckwalter for technical advice, and Y. Takeda-Uchimura for technical support.

*M.M. and T.F. contributed equally to this work.

Correspondence should be addressed to Tony Wyss-Coray, 1201 Welch Road, Room P208, MSLS Building, Stanford, CA 94305-5489. E-mail: twc@stanford.edu.

M. Britschgi's present address: CNS Discovery, pRED, F. Hoffmann-La Roche Ltd., Basel, Switzerland.

DOI:10.1523/JNEUROSCI.3617-10.2011

Copyright $\odot 2011$ the authors $\quad 0270-6474 / 11 / 313981-09 \$ 15.00 / 0$
Genetic studies in mouse models have illustrated the complex function complement has in the brain. For example, overproduction of the rodent complement C3 inhibitor Crry (Wyss-Coray et al., 2002) or lack of C3 (Maier et al., 2008) led to increased accumulation of $\beta$-amyloid in mouse models for Alzheimer's disease $(\mathrm{AD})$, whereas lack of $\mathrm{Clq}$ reduced neurodegeneration in another AD mouse model (Fonseca et al., 2004). Clq appears to have a role in synaptic pruning during development (Stevens et al., 2007), and chronic increases of C1q observed in many neurodegenerative diseases have been postulated to promote synapse elimination. Interestingly, complement C3 and C3aR deficiency were associated with reduced neurogenesis in unmanipulated brains and after stroke (Rahpeymai et al., 2006), supporting a role for $\mathrm{C} 3 \mathrm{a}$, a potent inflammatory mediator, in the regulation of adult neurogenesis.

The adult mammalian brain can form new neurons in the subventricular zone of the lateral ventricles and the subgranular zone of the dentate gyrus in the hippocampus. Newly born neurons can integrate into functional circuits in the olfactory bulb or hippocampus, respectively. While the consequences of this process, particularly in the human brain, are unclear (Leuner et al., 2006; Zhao et al., 2008), hippocampal neurogenesis is required in forming certain types of memories in mice (Dupret et al., 2008; Zhang et al., 2008). Interestingly, injury stimulates (Dash et al., 2001) whereas inflammation inhibits neurogenesis (Monje et al., 2002, 2003; Ekdahl et al., 2003). Basal and injury-induced production of new hippocampal neurons dramatically decreases with age, as does the ability of neural progenitor cells (NPCs) to proliferate (Kuhn et al., 1996; Yagita et al., 2001; Jin et al., 2004). This may be the result of both declining levels of mitogens, 

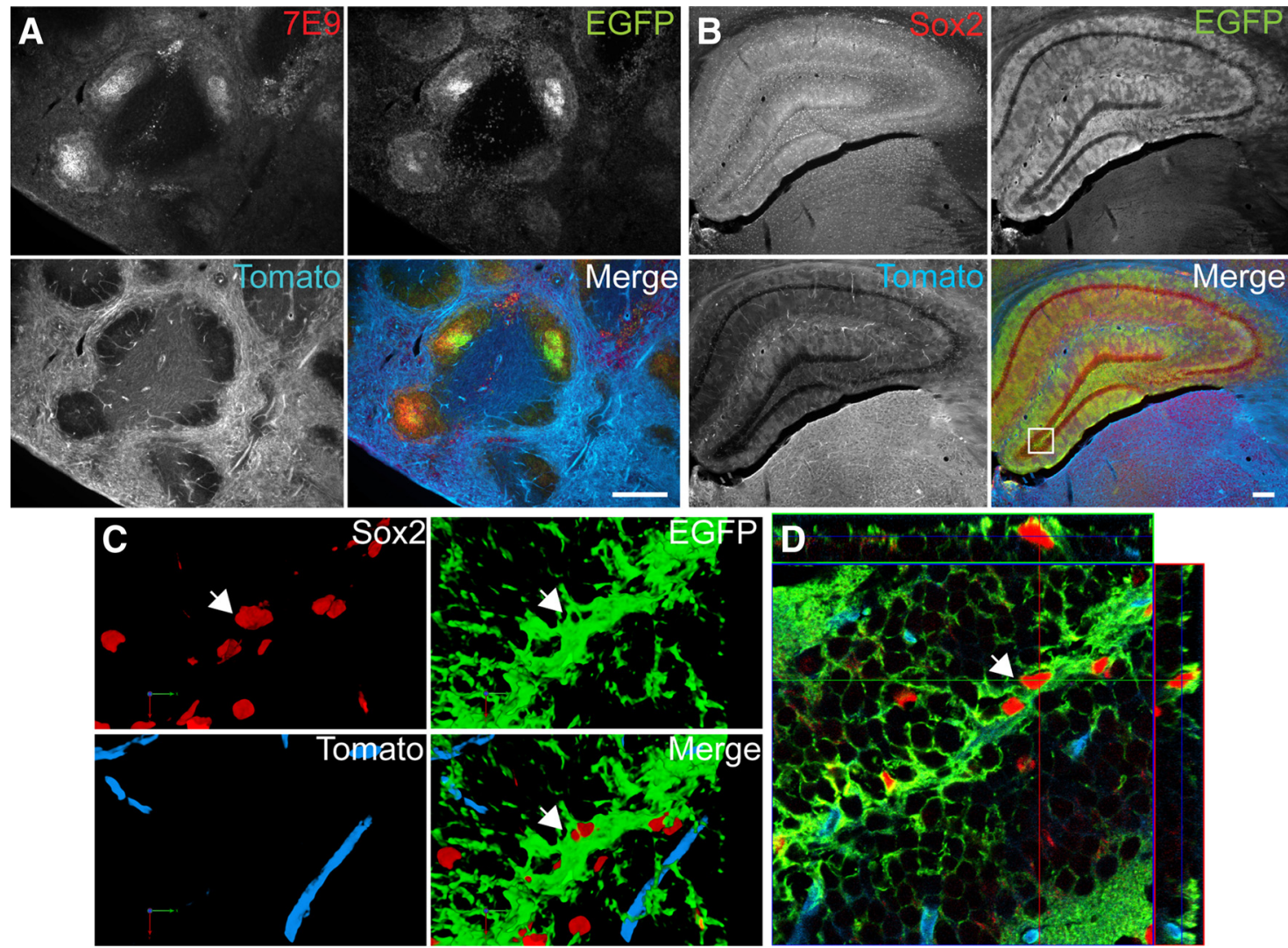

Figure 1. $\quad \boldsymbol{A}-\boldsymbol{D}, \mathrm{Cr2}$-cre-controlled EGFP reporter gene is expressed in NPCS of the subgranular zone. Representative images of EGFP-expressing cells in the spleen $(\boldsymbol{A})$, the hippocampus $(\boldsymbol{B})$, and the dentate gyrus $(\boldsymbol{C}, \boldsymbol{D})$ of a 2-month-old double-transgenic $\mathrm{Cr2}$-cre; $\mathrm{mT} / \mathrm{mG}$ reporter mouse. Ubiquitously expressed, membrane-targeted tandem dimmer Tomato is replaced by membranetargeted EGFP (mG) after cre-dependent recombination. A, Representative fluorescent microscopy images of the spleen labeled with an anti-Cr2 (CR2/CD35, clone 7E9) antibody (red), EGFP (green), or Tomato (blue). $\boldsymbol{B}$, Representative fluorescent microscopy images of the hippocampus stained with anti-Sox2 (red), EGFP (green), and Tomato (blue) from a (r2-cre; $\mathrm{mT} / \mathrm{mG}$ reporter mouse at low magnification. The merged image shows hippocampal cells expressing EGFP. C, High-magnification images of the boxed area in $\boldsymbol{B}$ (merged image) and three-dimensional reconstruction of a stack of deconvoluted confocal images. D, Orthogonal view of confocal microscopy images showing colocalization of membrane-targeted EGFP and Sox2 (arrow), which is an NPC marker in the subgranular zone. Scale bars, $300 \mu \mathrm{m}$.

growth, and survival factors (Anderson et al., 2002; Shetty et al., 2004) and increased abundance of inhibitory signals (Buckwalter et al., 2006), but more work is needed to understand the molecular mechanisms regulating adult neurogenesis. Because the complement system has broad functions in inflammation and cell homeostasis, we asked whether complement receptors may regulate neurogenesis.

\section{Materials and Methods}

Mice. Mice deficient in the $\mathrm{Cr} 2$ gene $\left(\mathrm{Cr}^{-/-}\right)$were obtained from $\mathrm{Dr}$. $\mathrm{H}$. Molina (Washington University, St. Louis, MO) (Molina et al., 1996). Mice deficient in the $\mathrm{Cr} 3$ gene $\left(\mathrm{Cr}^{-1-}\right)$ were obtained from T. Mayadas (Harvard Medical School, Boston, MA) (Coxon et al., 1996). Human CR2/CD21 transgenic mice harboring a bacterial artificial chromosome (BAC; hCD21 BAC; RP11-35C1; mouse line 38) express hCR2 under control of its natural human regulatory sequences (Hsiao et al., 2006). Cr2-Cre mice [B6.Cg-Tg(Cr2-cre)3Cgn/J; stock number 006368] harbor a transgene consisting of a cre recombinase expression cassette inserted into a BAC containing the mouse Cr2 locus (Kraus et al., 2004) and were obtained from The Jackson Laboratory. We used two lines of Cre reporter mice: a double-fluorescent reporter mouse [B6.129(Cg)-

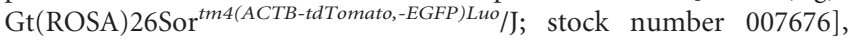
which harbors a chicken actin core promoter with a cytomegalovirus enhancer driving membrane-targeted tandem dimer Tomato (mT)polyA fragment flanked by loxP sites upstream of enhanced green fluorescent protein (EGFP) inserted into the ROSA26 locus (Muzumdar et

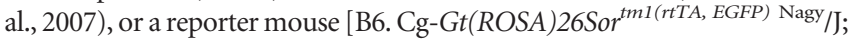
stock number 005670[, which harbors a PGK-neo-polyA fragment flanked by loxP sites upstream of rtTA and EGFP inserted into the ROSA26 locus (Belteki et al., 2005). Both mouse lines were obtained from The Jackson Laboratory and bred on an inbred C57BL/6J genetic background using wild-type mice from The Jackson Laboratory. We used male and female mice in all experiments and did not observe any significant differences in the measurements reported herein. All animal care and use was in accordance with institutional guidelines and approved by the Veterans Administration Palo Alto Committee on Animal Research.

Immunohistochemistry. Immunostaining of mouse brain tissue was performed as described previously (Buckwalter et al., 2006). Briefly, brains of mice were immersed in $4 \%$ paraformaldehyde (PFA) overnight at $4^{\circ} \mathrm{C}$, sunk through sucrose, and sectioned to $40 \mu \mathrm{m}$ in thickness with a cryomicrotome. For 3,3'-diaminobenzidine (DAB) staining, sections were incubated with primary antibody rat anti-bromodeoxyuridine (BrdU; $0.4 \mu \mathrm{g} / \mathrm{ml}$; Abcam) or goat anti-doublecortin (Dcx) $(0.4 \mu \mathrm{g} / \mathrm{ml}$; Santa Cruz Biotechnology) overnight at $4^{\circ} \mathrm{C}$, rinsed, and incubated with biotinylated rabbit anti-rat ( $1 \mu \mathrm{g} / \mathrm{ml}$, vector) or rabbit anti-goat antibody ( $3 \mu \mathrm{g} / \mathrm{ml}$, (Vector Laboratories) followed by ABC labeling (Vector Laboratories) and development with DAB (Sigma). For BrdU labeling, brain sections were pretreated with $2 \mathrm{~N} \mathrm{HCl}$ at $37^{\circ} \mathrm{C}$ for 30 min before incubation with a primary antibody. For multilabel immunofluorescence of BrdU and cell-type-specific markers, sections were incubated overnight with rat anti-BrdU, rinsed, and incubated for $1 \mathrm{~h}$ with donkey anti-rat antibody $(2.5 \mu \mathrm{g} / \mathrm{ml}$; Vector Laboratories) before they were stained with one or two of the following antibodies: goat anti-Dcx, mouse anti-GFAP (1:1000; Millipore), and mouse anti-NeuN (1.0 $\mu \mathrm{g} / \mathrm{ml}$; Millipore). To characterize green fluorescent protein (GFP)-expressing cells in the 

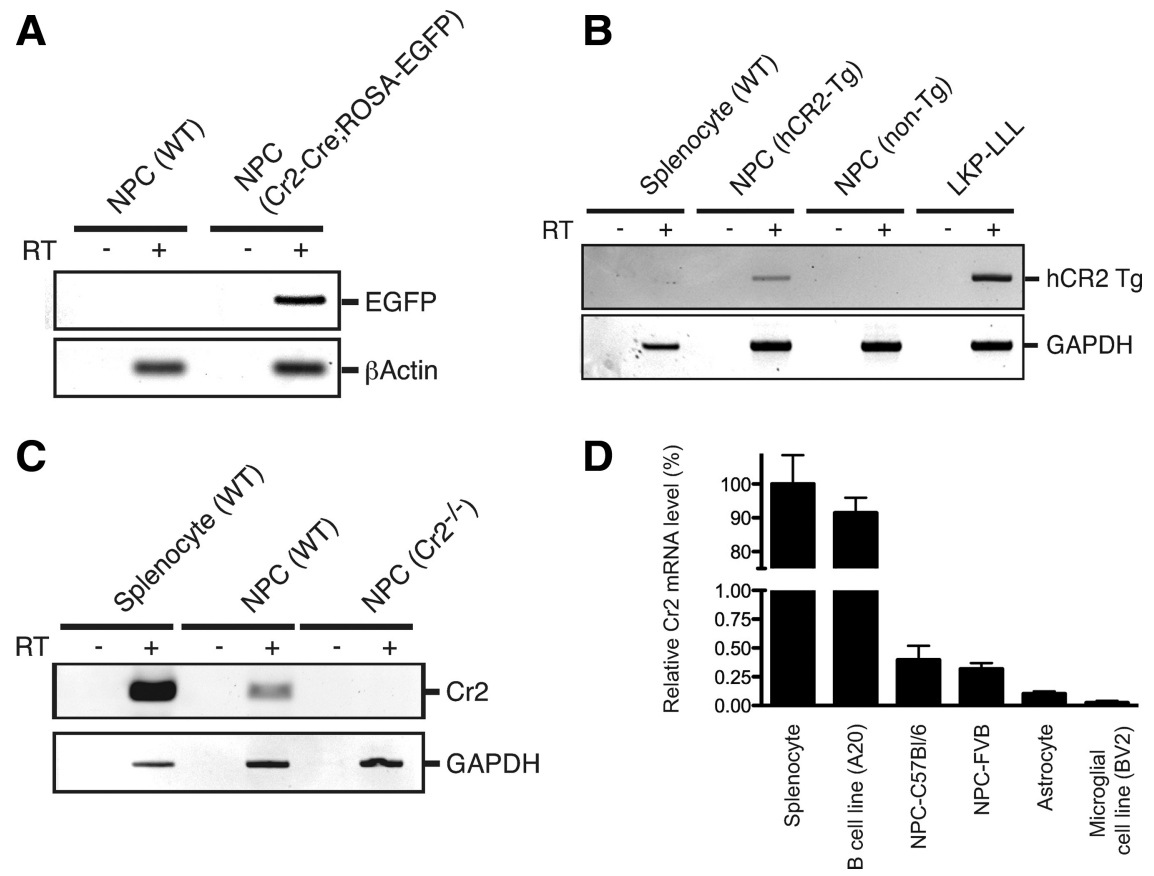

Figure 2. Cr2-controlled transcripts are expressed in NPCs. Total RNA was extracted from primary mouse NPCs, splenocytes, or the human B-cell lymphoma cell line LKPLLL and reverse transcribed, and segments of EGFP, mouse, or human CR2 were amplified. CDNA was synthesized with oligo-dT primers in the presence $(\mathrm{RT}+)$ or absence (RT -) of reverse transcriptase from total RNA extracts. $\beta$-Actin or GAPDH served as a loading controls. $A$, EGFP transcripts were detected in NPCs isolated from Cr2-Cre mice crossed with ROSA-EGFP reporter mice but not in wild-type littermate control mice. $\boldsymbol{B}$, Human CR2 transcripts were detected in transgenic NPCs from hCD21-BAC;Cr2 ${ }^{-1-}$ mice (hCR2-Tg) and in human B-cells (LKP-LLL) but not in nontransgenic NPCs or wild-type splenocytes. $C$, Endogenous mouse Cr2 transcripts were detected in splenocytes or NPCs from wild-type (WT) mice but not in NPCs derived from $\mathrm{Cr} 2 \mathrm{knock}$-out ( $\mathrm{Cr}{ }^{-1-}$ ) littermate controls. non-Tg, Nontransgenic. D, Quantification of endogenous $\mathrm{Cr} 2$ transcripts by qPCR. Sample cDNAs of spleen, the B-cell line A20, primary NPCs derived from P1 C57BL/6 wild-type or FVB wild-type mice, primary astrocytes, or the microglial cell line BV2. Samples were run in quadruplicates, and transcript levels were estimated based on standard curves generated for $\mathrm{C} 2$ or GAPDH. Relative $\mathrm{C} 2$ transcript levels are presented as a percentage of levels detected in spleen (100\%). Bars are mean + SEM.

spleen and the dentate gyrus of $\mathrm{mT} / \mathrm{mG}$ mice, anti-Cr2 (clone 7E9, 1:100; BioLegend) and anti-Sox2 (clone Y-17, 1:500; Santa Cruz Biotechnology) were used. Primary antibody staining was detected with secondary antibodies Cy3 donkey anti-rat (1:500; Jackson ImmunoResearch), Alexa 488 donkey anti-goat (100 $\mu \mathrm{g} / \mathrm{ml}$; Invitrogen), Alexa 546 donkey anti-mouse (100 $\mu \mathrm{g} / \mathrm{ml}$; Invitrogen), Alexa 488 donkey anti-mouse (100 $\mu \mathrm{g} / \mathrm{ml}$; Invitrogen), or Alexa 488 donkey anti-rabbit $(100 \mu \mathrm{g} / \mathrm{ml}$; Invitrogen). Fluorescence images were obtained using a confocal-laser microscope (LSM 510 meta Pascal; Carl Zeiss MicroImaging). Volocity software (PerkinElmer) was used for three-dimensional reconstruction with a coarse algorithm and deconvolution of $Z$-stack fluorescence images.

Quantification of Dcx-positive cells. To quantify Dcx staining in 8-week-old mice, MetaMorph imaging software (version 6.1r1; Molecular Devices) was used. The percentage of pixels above background staining within a region drawn around the dentate granule cell layer and subgranular zone was quantified. This method was used because the cell density was too high to count the cells in these $40-\mu$ m-thick sections using light microscopy. In all other mice, Dcx-positive cells in the same region were counted in every 12 th coronal section through the hippocampus, and the total number of $\mathrm{Dcx}+$ cells for each section was estimated by multiplying the number of cells counted by 12 .

BrdU labeling and quantification of BrdU-positive cells. BrdU (50 mg/ $\mathrm{kg}$ ) was injected intraperitoneally into 8-week-old mice once per day for $6 \mathrm{~d}$, and mice were killed $1 \mathrm{~d}$ (short-term labeling) (see Fig. 5) or $28 \mathrm{~d}$ (long-term labeling) (see Fig. 6) later. To estimate the total number of BrdU-positive cells in the brain, we performed DAB staining for BrdU on every sixth hemibrain section. BrdU + cells in the granule cell and subgranular cell layer of the dentate gyrus in hemibrain were counted blinded with respect to genotype. The total number of BrdU+ cells in these hippocampal regions was then estimated by multiplying the number of cells counted by 12. Confocal microscopy was used to examine 50-100 BrdU-positive cells from each mouse for each stain to determine whether they colabeled with Dcx, NeuN, or both, or with GFAP. The number of double- or triple-positive cells was expressed as a percentage of BrdU-positive cells.

Cell culture. Mouse NPCs were isolated from forebrains or hippocampi of postnatal day 0 (P0) to P3 mice and cultured as described previously (Reynolds and Rietze, 2005). Briefly, brains or hippocampi were dissected and incubated in DMEM containing $2.5 \mathrm{U} / \mathrm{ml}$ papain (Worthington Biochemicals), $250 \mathrm{U} / \mathrm{ml} \mathrm{DNa-}$ seI (Worthington Biochemicals), and $1 \mathrm{U} / \mathrm{ml}$ dispase II (Roche Diagnostics) at $37^{\circ} \mathrm{C}$ for 45 min. Undigested pieces of tissue were removed by centrifugation at $500 \times g$ for $5 \mathrm{~min}$, and NPCs were isolated using 65\% Percoll (GE Healthcare) in DMEM with 10\% FCS. Cellular pellets were resuspended in DMEM/F-12 containing $5 \mathrm{~mm}$ HEPES buffer, $0.6 \%$ glucose, 3 $\mathrm{mm}$ sodium bicarbonate, $2 \mathrm{~mm}$ L-glutamine, 20 $\mu \mathrm{g} / \mathrm{ml}$ insulin, $60 \mu \mathrm{M}$ putrescine, $100 \mu \mathrm{M}$ apotransferrin, $6.3 \mathrm{ng} / \mathrm{ml}$ progesterone, $5.2 \mathrm{ng} / \mathrm{ml}$ sodium selenite, $2 \mu \mathrm{g} / \mathrm{ml}$ heparin, $20 \mathrm{ng} / \mathrm{ml} \mathrm{ep}$ idermal growth factor (EGF), and $10 \mathrm{ng} / \mathrm{ml}$ basic FGF (bFGF), counted, and plated in uncoated plates at $1^{\prime} 10^{6}$ cells $/ \mathrm{ml}$. To prepare neurospheres from hippocampi, the Percoll purification step was found not to be necessary, and digested tissues were directly cultured in Neurobasal-A medium (Invitrogen) supplemented with B27 (Invitrogen), Glutamax (Invitrogen), and the growth factors EGF (20 ng/ $\mathrm{ml}$; PeproTech) and bFGF (20 ng/ml; PeproTech). To passage cells, neurospheres were harvested by centrifugation $(500 \times g$ for $5 \mathrm{~min})$ and dissociated in Hanks-based cell dissociation buffer (Invitrogen). Rat NPCs were cultured as described previously (Monje et al., 2003). Briefly, cells were grown in DMEM/F-12 supplemented with N2 supplement and 20 $\mathrm{ng} / \mathrm{ml}$ bFGF (PeproTech).

Reverse transcription-PCR and quantitative PCR analysis. Total RNA was extracted using Trizol reagent (Invitrogen) and treated with the TURBO DNA-free kit (Applied Biosystems) to digest DNA. Two micrograms of DNase-treated RNA samples were subjected to first-strand cDNA synthesis using oligo-dT primers supplied by the Taqman reverse transcription reagents kit (Applied Biosystems) by following the instruction manual. Primers used in this study are listed in supplemental Table 1 (available at www.jneurosci.org as supplemental material). For reverse transcription-PCR (RT-PCR), glyceraldehyde 3-phosphate dehydrogenase(GAPDH) and GFP transcripts were amplified using ExTaq polymerase (Takara). $\mathrm{Cr} 2$ and $\beta$ actin transcripts were amplified using AmlpiTaqGold (Applied Biosystems) polymerase. For quantitative PCR (qPCR), gene-specific primer sets designed by either PrimerBank (http:// pga.mgh.harvard.edu/primerbank/index.html) or RTPrimerDB (http:// medgen.ugent.be/rtprimerdb/) were verified to produce single amplification products by gel electrophoresis. Using SYBR Green PCR Master mix (Applied Biosystems), reaction products were quantified and normalized to standard curves generated separately for each transcript from mRNA obtained from A20 cells $\left(R^{2}=0.9873\right.$ for $\mathrm{Cr} 2, R^{2}=0.9835$ for GAPDH). SDS2.3 software from the ABI9700HT system (Applied Biosystems) was used to process data.

Neurosphere assay. To assess the number of neurospheres, $1 \times 10^{3}$ mouse NPCs at passage 5 were seeded per well in 96 -well plates and incubated for $48 \mathrm{~h}$ at $37^{\circ} \mathrm{C}$ in the presence or absence of CR2 ligands and various antibodies. The total number of neurospheres in each well with 
diameters $>50 \mu \mathrm{m}$ were counted. Neurosphere size was evaluated using MetaMorph imaging software (version 6.1r1; Molecular Devices). The cell number per dissociated sphere was analyzed from the same cultures using a standard Neubauer counting chamber. Cells were treated with the following proteins or antibodies: purified human C3 and human C3d (Complement Technology); recombinant mouse interferon $\alpha \mathrm{A}$ (IFN $\alpha$; PBL Interferon Source); monoclonal rat anti-mouse CD35/CR2 antibody (clone 7G6; BD Biosciences); polyclonal rabbit anti-human C3d (Dako); and biotin rat IgG2a isotype control antibody (BioLegend).

Rat NPC line proliferation assay. A total of $1 \times 10^{4}$ rat NPCs were incubated with $\mathrm{C} 3$ or $\mathrm{C} 3 \mathrm{~d}$ at the indicated concentration at $37^{\circ} \mathrm{C}$ for $48 \mathrm{~h}$ before cell counting. A rabbit antibody against human C3d (1:1000; Dako) was used for blocking C3d.

Stereotaxic injections and BrdU labeling. Purified human C3d $(0.5 \mu \mathrm{g}$ in $0.5 \mu \mathrm{l}$ ) was injected stereotaxically into the right side of the dentate gyrus, and an equal amount of saline was injected into the left side $(1.75 \mathrm{~mm}$ posterior, $0.75 \mathrm{~mm}$ lateral, $1.7 \mathrm{~mm}$ ventral from bregma). After mice gained consciousness from surgery, $50 \mathrm{mg} / \mathrm{kg}$ BrdU was injected intraperitoneally once and then again daily for $5 \mathrm{~d}$ until mice were killed on day 7. Brains were removed, immersed in $4 \%$ PFA overnight at $4^{\circ} \mathrm{C}$, sunk through sucrose, and sectioned to $40 \mu \mathrm{m}$ in thickness with a cryomicrotome. Five sections close to the injection site were then stained with antibodies against BrdU and Dcx as described above. The number of $\mathrm{BrdU}+/ \mathrm{Dcx}+$ double-positive cells was counted using confocal microscopy on the C3d- or saline-injected sides on the one section most proximal to the injection site per mouse, and the ratio of double-labeled cells between C3d- and saline-injected sides was calculated.

Statistical analysis. All immunohistochemical experiments were analyzed by an investigator blinded to genotype or age. Values are presented as mean + SEM. Differences among groups were analyzed using $t$ test or one-way ANOVA with the Scheffé's post hoc test. $p$ values $\leq 0.05$ were considered to be significant. Analyses were done using Statview software.

\section{Results}

\section{$\mathrm{Cr} 2$ and related adaptor genes are expressed in NPCs}

Injury and inflammation are potent regulators of adult neurogenesis (Dash et al., 2001; Monje et al., 2002, 2003; Ekdahl et al., 2003). To determine whether complement factors are involved in this process, we asked whether complement receptors are expressed in NPCs. Whereas CR3 (CD11b/CD18) and CR4 (CD11c/CD18) are accepted markers for the myeloid lineage, expression of the $\mathrm{Cr} 2$ gene product CR2, which is involved in multiple stages of B-lymphocyte differentiation and proliferation (Tolnay and Tsokos, 1998; Carroll, 2004), has not been studied in neurogenesis. To track $\mathrm{Cr} 2$ gene expression in vivo, we crossed Cr2-cre transgenic mice [B6.Cg- $\mathrm{Tg}(\mathrm{Cr} 2-\mathrm{cre}) 3 \mathrm{Cgn} / \mathrm{J}$ ] (Kraus et al., 2004), which harbor cre recombinase inserted into a mouse Cr2 BAC clone, with ROSA26-Actin promoter-loxP-mT-pAloxP-mEGFP-pA reporter mice (herein called $\mathrm{mT} / \mathrm{mG}$ mice) (Muzumdar et al., 2007). In double-transgenic mice, cre-induced recombination in $\mathrm{Cr}$-expressing cells leads to excision of the gene encoding for membrane-targeted tandem dimer Tomato and a stop sequence resulting, in turn, in expression of membrane-targeted EGFP. Thus, every cell in this mouse either expresses Tomato or EGFP. To validate the Cr2-driven Cre reporter system, we stained spleen tissue sections with the anti-Cr2 antibody 7E9 and compared it with Cr2-cre-induced EGFP protein expression in 2-month-old $\mathrm{Cr} 2$-cre; $\mathrm{mT} / \mathrm{mG}$ reporter mice. We observed that all EGFP-expressing cells also labeled with the $\mathrm{Cr} 2$ antibody (Fig. 1A). In the brain, EGFP-positive cells were found throughout the hippocampus (Fig. $1 B$ ), suggesting that these cells are still expressing CR2 or that they descended from CR2-expressing precursors. Higher-power confocal images showed that many of the cells in the subgranular zone of the dentate gyrus also expressed Sox2, consistent with characteristics
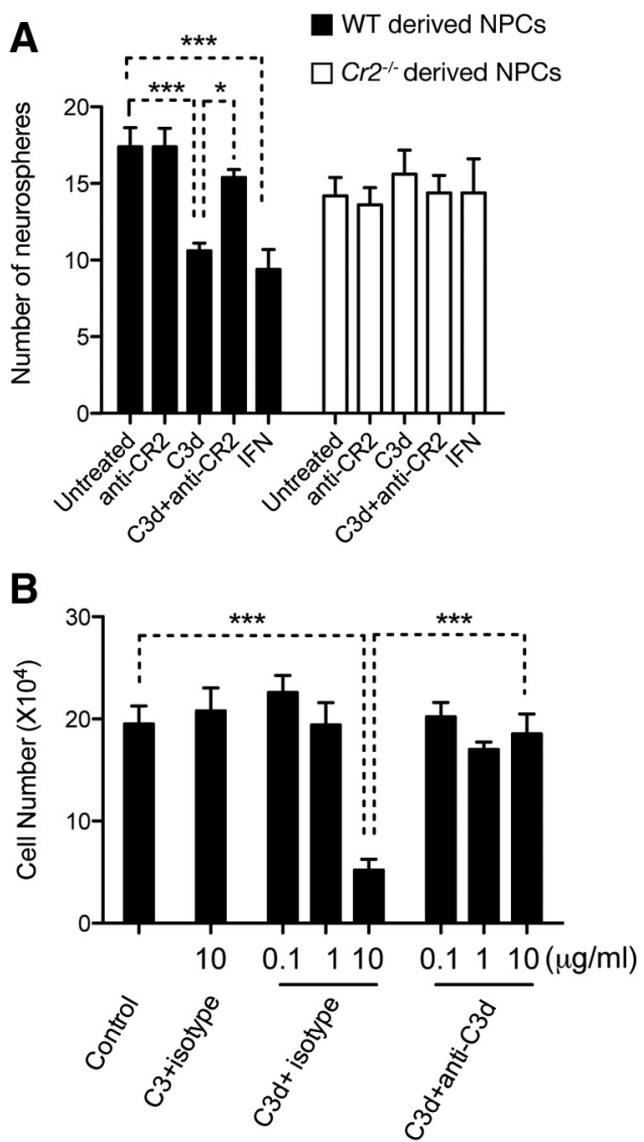

Figure 3. CR2 ligands reduce the number of neurospheres in cultures of primary mouse NPCs and a rat NPC line. $\boldsymbol{A}$, Primary mouse NPCs were isolated from hippocampi of newly born $\mathrm{Cr}^{-1-}$ (open bars) and wild-type (WT; filled bars) mice, and established cultures at passage 5 were treated with purified human C $3 \mathrm{~d}(10 \mu \mathrm{g} / \mathrm{ml})$ in the presence or absence of anti-CR2/CD35 antibody $7 \mathrm{G6}$, which blocks ligand binding, with IFN- $\alpha(1000 \mathrm{U} / \mathrm{ml})$, or with vehicle or an isotype control antibody for $48 \mathrm{~h}$. The average number of neurospheres $>50 \mu \mathrm{m}$ per field (average of 3 fields at $20 \times$ magnification) from triplicate cultures are shown. Note the inhibitory effect of CR2 ligands in WT but not in $\mathrm{Cr}^{-1-}$ NPCs. $\boldsymbol{B}$, Rat NPCs $\left(1 \times 10^{4}\right)$ were seeded in six-well plates and treated with purified human $\mathrm{C} 3$ or $\mathrm{C} 3 \mathrm{~d}$ at the indicated concentrations or with C $3 \mathrm{~d}$ together with a $\mathrm{C} 3 \mathrm{~d}$-neutralizing antibody or a control isotype antibody. The cell number was counted after $48 \mathrm{~h}$. Bars represent mean + SEM from triplicate cultures from one of three representative experiments. ${ }^{*} p<0.05,{ }^{* * *} p<0.001$, by one-way ANOVA and Scheffé's post hoc test.

of NPCs (Fig. 1C, D; supplemental Video 1, available at www.jneurosci.org as supplemental material).

Because none of the available $\mathrm{Cr} 2$ antibodies produced specific staining on brain sections if $\mathrm{Cr} 2$ knock-out mice were used as a control (supplemental Table 2, available at www.jneurosci. org as supplemental material), we measured Cr2 mRNA in brain tissue and cells. In support of $\mathrm{Cr} 2$ promoter activity in NPCs, EGFP mRNA was expressed in freshly isolated neonatal NPCs from Cr2-cre;ROSA26-GFP reporter mice that harbor the ROSA26-loxP-stop-loxP-rtTA-IRES-EGFP reporter construct (Fig. $2 \mathrm{~A}$ ). Additional evidence that the CR2 promoter is active in NPCs was obtained from "humanized" CR2 transgenic mice in which an artificial bacterial chromosome containing the human CR2 locus (which does not contain the independent CD35 gene) leads to human CR2 (hCD21) expression under control of the human promoter, for example, in B-cells (Hsiao et al., 2006). In addition, the mice were crossed onto the $\mathrm{Cr} 2^{-1-}$ background, essentially replacing mouse $\mathrm{Cr} 2$ with human CR2. Notably, CD35 (endogenous mouse and human) is lacking in these mice. 
A
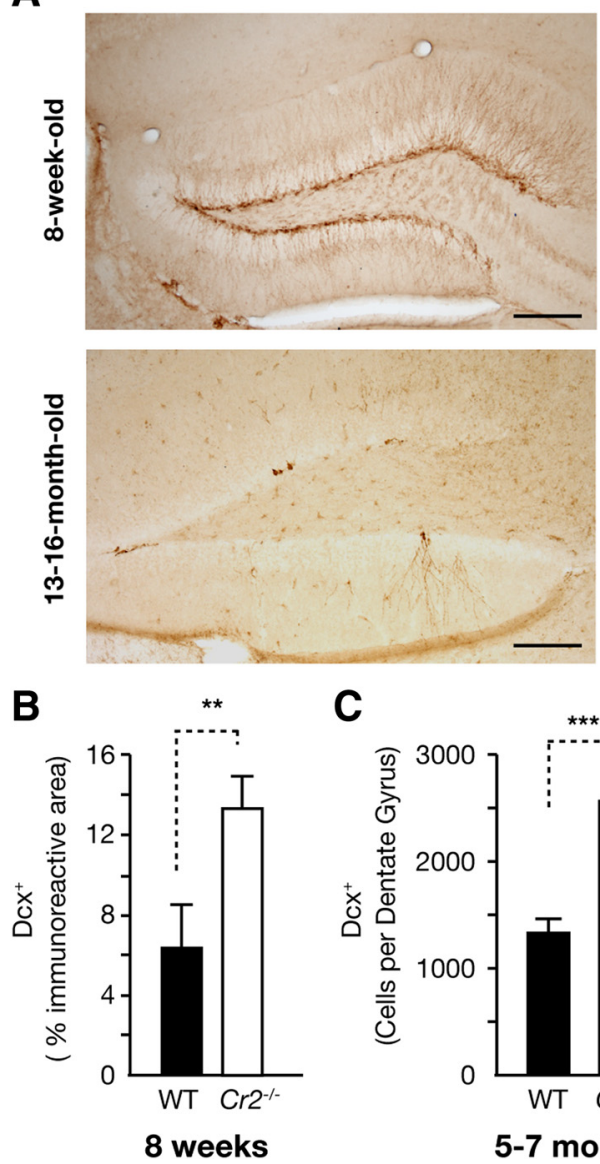

C

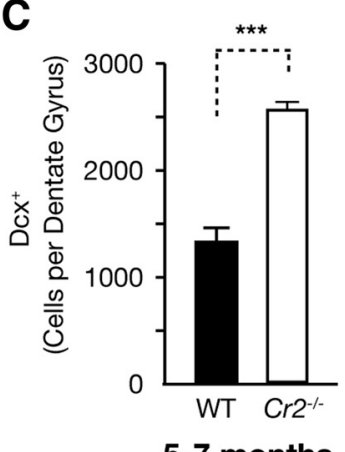

$\mathrm{Cr}^{-1-}$
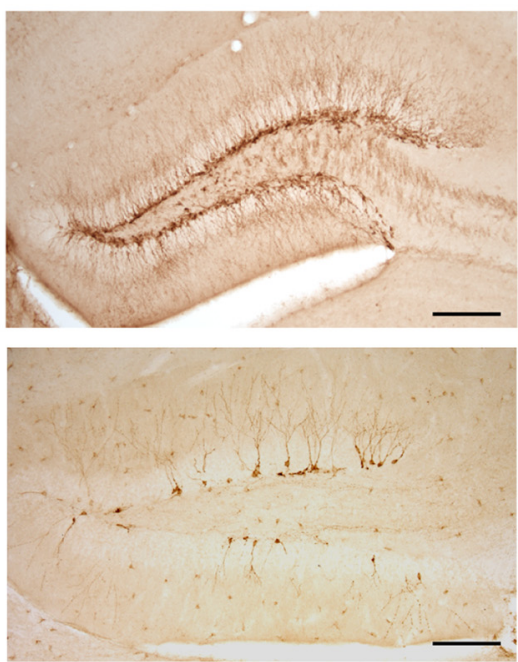

D

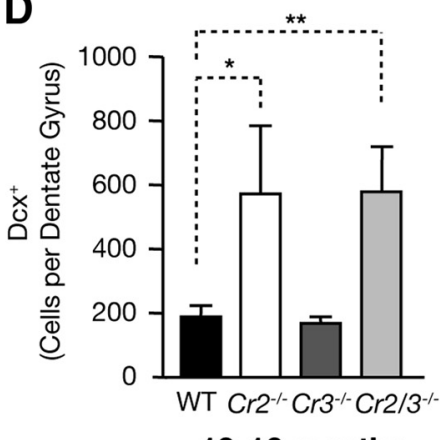

Figure 4. $\mathrm{Cr}^{-1-}$ mice exhibit increased neurogenesis. Brains of $\mathrm{Cr}^{-1-}$ mice and wild-type littermate controls at 8 weeks or 5-7 months of age or littermates from a cross of $\mathrm{Cr}^{-1-}$ with $\mathrm{Cr}^{-1-}$ mice at 13-16 month of age were analyzed for expression of $D c x$, a marker of proliferating neuroblasts and immature neurons, in the dentate gyrus. $\boldsymbol{A}$, Representative images depicting the dentate gyrus from $40 \mu \mathrm{m}$ brain sections of 8-week-old and 13- to 16-month-old $\mathrm{Cr}^{-1-}$ and wild-type (WT) mice immunostained with anti-Dcx antibodies and developed with immunoperoxidase and diaminobenzidine. Scale bars, $200 \mu \mathrm{m} . \boldsymbol{B}-\boldsymbol{D}$, Quantitative analysis of $D c x$ immunostaining assessed as the relative area of the dentate gyrus occupied by immunoreactive label $(\boldsymbol{B})$ or number of positive cells per dentate gyrus per mouse $(\boldsymbol{C}, \boldsymbol{D})$ at the indicated ages. Note the prominent increase in $D c x+$ neuroblasts in $\mathrm{Cr}^{-1-}$ and $\mathrm{Cr}_{2} / 3^{-1-}$ compared with $\mathrm{Cr}^{-1-}$ or wild-type mice. Bars represent mean $+\mathrm{SEM} ; n=4-8$ mice per group. ${ }^{*} p<0.05 ;{ }^{* *} p<0.01 ;{ }^{* * *} p<0.001$, by $t$ test $(\boldsymbol{B}, \boldsymbol{C})$ or one-way ANOVA and Scheffé's post hoc test (D).

We observed that NPCs from these hCD21-BAC;Cr2 ${ }^{-1-}$ mice expressed human CR2 mRNA, whereas NPCs from nontransgenic mice did not (Fig. $2 B$ ). These findings strongly suggest that NPCs express CR2. Last, neonatal wild-type primary mouse NPCs expressed Cr2 mRNA by RT-PCR, whereas $\mathrm{Cr}^{-1-}$ NPCs did not (Fig. 2C). To assess relative levels of $\mathrm{Cr} 2$ expression, we compared transcript levels in NPCs with those in lymphoid tissue and other CNS cells using qPCR. Although NPCs isolated from C57BL/ 6 or FVB mouse strains expressed $<1 \%$ of Cr 2 mRNA compared with spleen or B-cell line A20, they expressed three to four times the amount detected in primary astrocytes (Fig. 2D). Microglia showed no detectable Cr2 mRNA (Fig. 2D). Because CD35 and CR2 are splice products encoded by the same gene in mice (i.e., Cr2) and differ from each other only by several identical so-called short consensus repeats (Carroll, 2004), we were not able to amplify specific transcripts discerning the splice variants.

CR2 is a key module of the B-cell antigen receptor complex together with CD19, CD81, and CD225, and therefore we asked whether these other components are also expressed in NPCs. Indeed, we were able to detect mRNAs encoding for all three components (supplemental Fig. S1, available at www.jneurosci.org as supplemental material), which are involved, in part, in B-cell receptor signal transduction. Together, these findings show $\mathrm{Cr} 2$ is expressed in mouse NPCs and raise the question whether it is functionally active.

\section{CR2 ligands inhibit NPC proliferation}

In B-cells, CR2 together with several adaptor proteins functions as the coreceptor for membrane-bound Igs (i.e., the B-cell receptor) by binding antigens coated with the complement adjuvant C3d, thus playing an important role in the activation and proliferation of B-cells (Tolnay and Tsokos, 1998; Carroll, 2004). To determine the functionality of CR2 in NPCs, we cultured primary postnatal NPCs derived from hippocampi or the entire forebrain from $\mathrm{Cr} 2^{-1-}$ mice (Molina et al., 1996) and wild-type littermate controls, as well as previously characterized rat NPC lines (Monje et al., 2003) in the presence and absence of CR2 ligands. We first tested the effect of human C3d, which is a functional ligand of the mouse CR2 receptor (Molina et al., 1991). In the absence of ligands, there was no consistent difference in the number or size of neurospheres at various passages between cultures derived from $\mathrm{Cr} 2^{-1-}$ mice or wild-type littermates (supplemental Fig. S2, available at www.jneurosci.org as supplemental material), and there were no apparent morphological differences in cell size or shape (data not shown). Treatment of hippocampal-derived wild-type primary mouse NPCs with purified human C3d reduced neurosphere number by onethird but had no effect on $\mathrm{Cr} 2^{-1-}$ NPCs (Fig. 3A). Consistent with these findings, C3d also reduced proliferation in the rat NPC line, whereas C3d incubated with C3d-neutralizing antibody or intact C3 had no effect on cell proliferation (Fig. 3B). Complement C3d or C3 did not induce overt cell death as no significant increase in lactate dehydrogenase could be measured in culture supernatants from C3d- or C3-treated compared with untreated NPCs (data not shown). The cytokine IFN- $\alpha$ has recently been shown to signal through the same domains of human CR2 as C3d and to bind to it with similar affinity (Asokan et al., 2006). Consistent with being a ligand for CR2, IFN- $\alpha$ significantly inhibited proliferation in wild-type but not $\mathrm{Cr}^{-/-}$primary mouse NPCs (Fig. 3A). Furthermore, the decrease in proliferation seen in wild-type primary mouse NPCs was reversed by the addition of antibody 7G6, which blocks ligand binding to CR2 (Martin et al., 1991), further supporting that C3d and IFN- $\alpha$ inhibit NPC proliferation in our cell-culture system by binding to CR2. In line with these results, neurosphere number and the number of cells per neurospheres were reduced after C3d or IFN- $\alpha$ treatment in wild-type NPCs derived from entire mouse forebrains but not in $\mathrm{Cr}^{-1-}$ NPCs (supplemental Fig. S3, available at www.jneurosci.org as supplemental material). In summary, these findings demonstrate the 
functional expression of $\mathrm{Cr} 2$ in cultured mouse and rat NPCs and show that CR2 ligands inhibit NPC proliferation.

Lack of $\mathrm{Cr} 2$ in mice results in increased basal neurogenesis

To investigate whether CR2/CD35 have a role in adult neurogenesis in vivo, we assessed expression of Dcx, a marker of proliferating neuroblasts and immature neurons, in $\mathrm{Cr} 2^{-1-}$ and wild-type littermates. We also analyzed neurogenesis in mice deficient in $\mathrm{Cr} 3$, a major phagocyte receptor restricted to microglia and macrophages in the brain, or in crosses resulting from these mice and lacking both $\mathrm{Cr} 2$ and $\mathrm{Cr} 3$. Lack of $\mathrm{Cr} 2$ resulted in a twofold increase in Dcx immunoreactivity in the dentate gyrus at 8 weeks and 5-7 months of age (Fig. $4 A-C$ ) and an almost threefold increase in the number of Dcx + cells in 13 - to 16 -month-old $\mathrm{Cr} 2^{-1-}$ mice compared with wild-type controls (Fig. $4 A, D)$. In contrast, littermate mice deficient in $\mathrm{Cr} 3$ showed no changes in the number of Dcx-expressing cells compared with wild-type controls (Fig. 4D). Mice lacking $\mathrm{Cr} 2$ and $\mathrm{Cr} 3$ showed equal increases in Dcx-expressing cells as $\mathrm{Cr}^{-1-}$ mice (Fig. $4 D$ ).

To determine whether lack of $\mathrm{Cr} 2$ led to an increase in proliferation in the hippocampus, the nucleotide analog BrdU was injected into mice for $6 \mathrm{~d}$, and the commitment of newly generated cells was evaluated $1 \mathrm{~d}$ later. NPCs in the subgranular zone of the dentate gyrus are capable of differentiating into either the neuronal or glial lineage. Whereas the total number of $\mathrm{BrdU}+$ cells in the dentate gyrus was not significantly different between wild-type and $\mathrm{Cr} 2^{-1-}$ mice in this short-term labeling paradigm (Fig. 5A), the number of BrdU $+/$ Dcx + cells was slightly but significantly increased in $\mathrm{Cr} 2^{-1-}$ mice (Fig. $5 B-$ $D)$. As expected, over this short time only few dividing cells acquired a NeuNpositive phenotype, and this was not changed by the lack of $\mathrm{Cr} 2$. The commitment of NPCs to the glial lineage was assessed using GFAP as a marker for astrocytes. No significant difference was observed in BrdU+/GFAP+ cells between wildtype and $\mathrm{Cr}^{-1-}$ mice after short-term labeling with BrdU (Fig. $5 B-D)$. Nevertheless, out of all dividing cells, the percentage of GFAP-expressing and other non-neuronal dividing cells was reduced from 32.6 to $20.8 \%$ in $\mathrm{Cr} 2^{-1-}$ mice compared with wildtype littermate controls, whereas the number of cells in the neuronal lineage increased from 67.4 to $79.2 \%$ (Fig. 5D).

To determine whether the increase in Dcx + cells observed in $\mathrm{Cr} 2^{-1-}$ mice is the result of changes in the maturation and survival of newly generated immature neurons, we analyzed the number of label-retaining neurons $28 \mathrm{~d}$ after BrdU injection. In this long-term labeling paradigm, $\mathrm{Cr} 2^{-1-}$ mice at 8 weeks of age
B
$\mathrm{BrdU}^{+} / \mathrm{Dcx}^{+} / \mathrm{NeuN}^{+} \quad \mathrm{BrdU}^{+} / \mathrm{GFAP}^{+}$

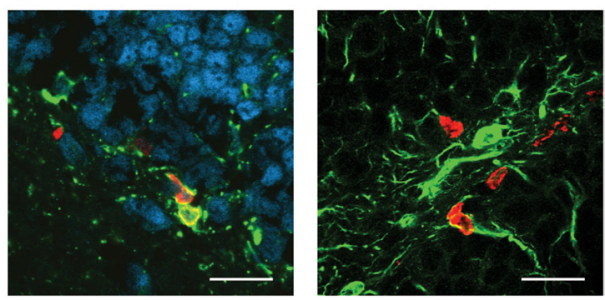

WT $\mathrm{Cr}^{-/-}$
C

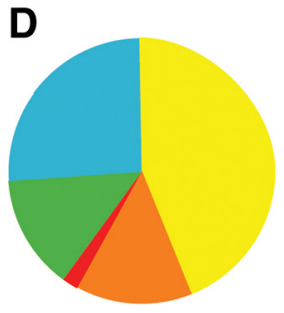

\section{Wildtype}

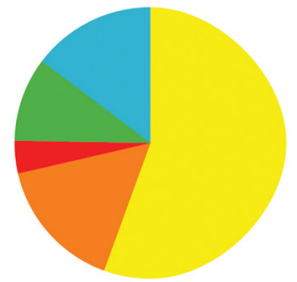

$\mathrm{Cr}^{-1-}$ $\square \mathrm{BrdU}^{+} / \mathrm{DCX}+$

$\square \mathrm{BrdU}^{+} / \mathrm{DCX}^{+} / \mathrm{NeuN}^{+}$

$\square \mathrm{BrdU}^{+} / \mathrm{NeuN}^{+}$

$\square \mathrm{BrdU}^{+} / \mathrm{GFAP}^{+}$

$\square$ Others
Figure 5. Differentiation of newly generated BrdU+ cells into the neuronal lineage is increased in $\mathrm{Cr}^{-1-}$ mice. After a short-term labeling protocol, 8-week-old $\mathrm{Cr}^{-1-}$ mice and wild-type (WT) littermate controls ( $n=5$ mice per group) were and $\mathrm{C}_{2}{ }^{-1-}$ mice. n.s., Nonsignificant. $\boldsymbol{B}$, Representative confocal microscopy images from the subgranular zone of the dentate fus of brain sections immunostained for BrdU (red) in combination with Dcx (green) and NeuN (blue; BrdU +/Dcx +/NeuN +) or $2^{-1-}$ mice, whereas BrdU $+/$ GFAP + cells were unchanged. Bars represent mean + SEM. ${ }^{*} p<0.05$, by one-way ANOVA and Scheffé's post hoc tests. D, Cell fate of newly generated neural cells $1 \mathrm{~d}$ after BrdU labeling of all BrdU-positive cells (each pie represents $100 \%$ of BrdU+ cells).

(Fig. 6A) and, more profoundly, at 5-7 months of age (Fig. 6A) had significantly more BrdU+ cells overall than wild-type mice, and there were more mature $\mathrm{BrdU} / \mathrm{NeuN}+$ neurons in $\mathrm{Cr} 2^{-1-}$ mice at 8 weeks of age (Fig. $6 B, C$ ).

Treatment with CR2 ligand reduces the number of proliferating neuroblasts in vivo

To determine whether $\mathrm{Cr} 2$ encodes a functional gene product in NPCs and CR2/CD35 signaling affects neurogenesis in vivo, we stereotaxically injected C3d into the right dentate gyrus of wildtype or $\mathrm{Cr} 2^{-1-}$ mice. Saline was injected as a control into the left dentate gyrus, and BrdU was given for $6 \mathrm{~d}$ intraperitoneally until the mice were killed the next day. Injection of $\mathrm{C} 3 \mathrm{~d}$ resulted, on 
A

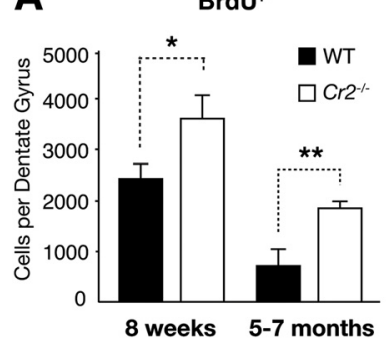

B

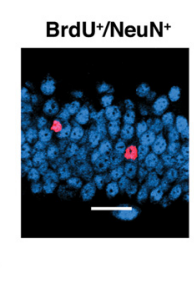

C $\mathrm{BrdU}^{+} / \mathrm{NeuN}^{+}$

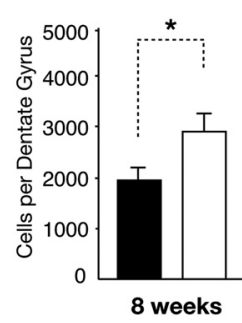

Figure 6. Number of newly generated mature neurons is increased in $\mathrm{Cr}^{-1-}$ mice. After a long-term labeling protocol, 8-week-old $\mathrm{Cr}^{-1-}$ mice and wild-type littermate controls ( $n=$ 8 mice per group) were injected once with BrdU and killed $28 \mathrm{~d}$ later. $\boldsymbol{A}$, The total number of $\mathrm{BrdU}+$ cells was increased in $\mathrm{Cr}^{-1-}$ mice at 8 weeks and at $5-7$ months of age. $\boldsymbol{B}$, Representative confocal microscopy image from the granular cell layer of the dentate gyrus from a brain section immunostained for BrdU (red) and NeuN (blue). Scale bar, $20 \mu$ m. C, Total number of BrdU $+/ \mathrm{NeuN}+$ mature neurons was increased in $\mathrm{Cr}^{-1-}$ mice at 8 weeks of age. Bars represent mean + SEM. ${ }^{*} p<0.05$, by $t$ test.

average, in a $35 \%$ decrease in the number of BrdU/Dcx + cells in the ipsilateral compared with the saline-injected side. Consistent with cell culture data, C3d had no effect in $\mathrm{Cr} 2^{-1-}$ mice (Fig. 7). These findings further corroborate the cell-culture studies suggesting that CR2/CD35 is functionally expressed in the hippocampus and can modulate adult neurogenesis in vivo.

\section{Discussion}

The complement system is best known for its critical functions in the immune system, but a growing number of studies have tied complement factors genetically to neurodegenerative diseases in humans and mice (Wyss-Coray et al., 2002; Haines et al., 2005; Klein et al., 2005; Maier et al., 2008). Most recently, the human CR1 locus was linked to AD in a large genome-wide association study (Lambert et al., 2009), although the biological role of CR1 in that disease, or in the brain in general, is unknown. Here we describe that $\mathrm{Cr} 2$, best known for encoding a key component of the B-cell receptor complex, is functionally expressed in NPCs. We demonstrate that $\mathrm{Cr}^{-1-}$ mice exhibit increased numbers of immature and mature neurons in the hippocampus, implicating $\mathrm{Cr} 2$ in the maintenance of adult neurogenesis. Conversely, C3d and IFN- $\alpha$, two independent ligands of human CR2/CD21, inhibit NPC proliferation in cell culture, and injection of C3d into the dentate gyrus reduces the number of immature neuroblasts in vivo.

Our findings add C3d and IFN- $\alpha$ to a growing number of immune molecules and inflammatory proteins that regulate adult neurogenesis in rodents. For example, interleukin- $1 \beta$ (IL$1 \beta)$ (Koo and Duman, 2008), IL-6 (Monje et al., 2003), tumor necrosis factor- $\alpha$ (Iosif et al., 2006), and transforming growth factor- $\beta$ (Buckwalter et al., 2006; Wachs et al., 2006) inhibit neurogenesis. It is unclear whether these factors are merely sufficient to inhibit adult neurogenesis when increased or whether they are also required to exert a certain negative signal to maintain homeostatic levels of neurogenesis. On the other hand, immune regulatory factors such as IL-6, leukemia inhibitory factor, or ciliary neurotrophic factor that signal through gp130 can stimulate neural stem cell proliferation or maintain stem cell fate (Shimazaki et al., 2001; Bauer and Patterson, 2006). The relative importance of these proteins needs to be determined as it is unclear whether they act alone or in concert and whether individual proteins are restricted to specific injury and disease conditions.

We report that lack of $\mathrm{Cr} 2$ in mice leads to a twofold to threefold increase in the number of immature neuroblasts (Fig. 4) and
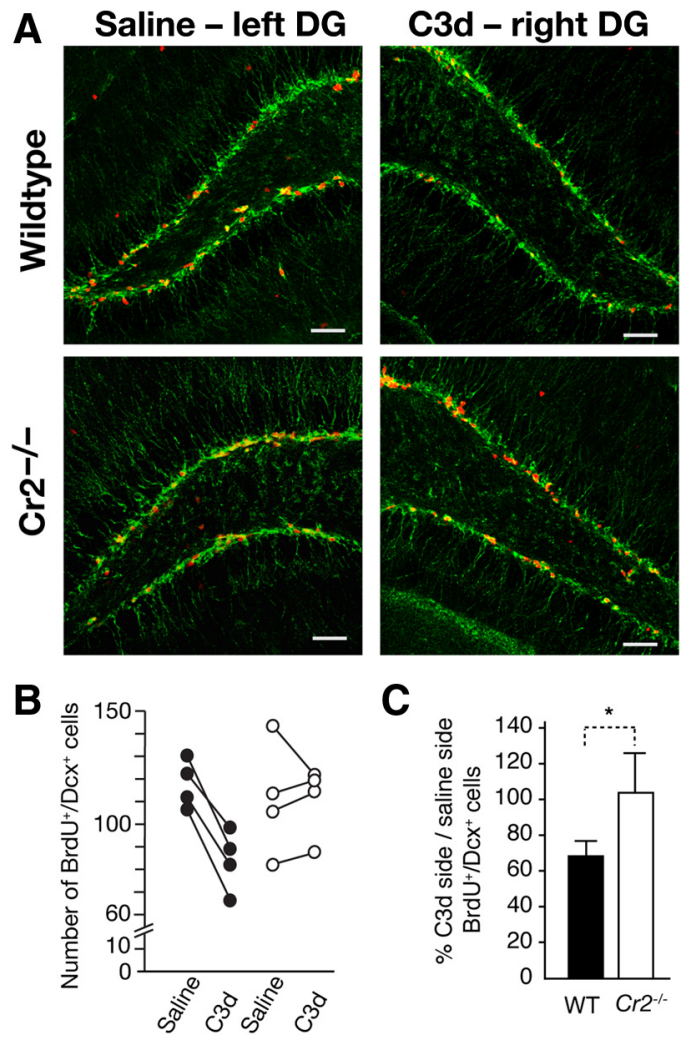

Figure 7. Acute $\mathrm{C} 3 \mathrm{~d}$ administration reduces the number of BrdU + neuroblasts in wild-type but not $\mathrm{Cr}^{-1-}$ littermate control mice. Four-month-old $\mathrm{Cr}^{-1-}$ mice and wild-type littermate controls ( $n=4$ mice per group) were given intracerebral injections of purified human C $3 \mathrm{~d}$ $(0.5 \mu \mathrm{g}$ in $0.5 \mu \mathrm{l})$ and an equal volume of saline into the right and left dentate gyrus, respectively. BrdU was injected once daily until mice were killed $7 \mathrm{~d}$ later. $\boldsymbol{A}$, Representative confocal image of the C3d-injected (right) and saline-injected (left) dentate gyrus (DG) from a single coronal brain section of a wild-type and $C 2^{-1-}$ mouse double stained for Dcx (green) and BrdU (red). Scale bars, $50 \mu \mathrm{m}$. B, Average number of BrdU $+/ D c x+$ cells per brain section for four individual mice per genotype. Connected dots represent the average number of cells on the saline- and C $3 \mathrm{~d}$-injected side of each mouse. Note the reduction in cell number on the C $3 \mathrm{~d}$ injected site in wild-type but not in $\mathrm{Cr}^{-1-}$ mice. $\mathbf{C}$, Calculation of the ratio of the average number of BrdU $+/ D c x+$ cells on the C $3 d$-injected compared with the saline-injected side in wild-type (WT) compared with $\mathrm{C}\left(2^{-1-}\right.$ mice. Bars represent mean + SD. ${ }^{*} p<0.05$, by Student's $t$ test.

an $\sim 40 \%$ increase in mature neurons (Fig. $6 C$ ) in the young adult hippocampus, suggesting CR2/CD35 may have a physiological role in the control of NPC number in the adult mouse by exerting a tonic inhibitory signal. In support of this, lineage tracing studies using a Cr2-cre-controlled reporter gene indicate that $\mathrm{Cr} 2$ is expressed in a small set of cells in the subgranular layer of the dentate gyrus that show neural stem cell-like characteristics expressing Sox2 (Fig. 1). Lack of $\mathrm{Cr} 2$ may also lead to an expansion of such early, possibly uncommitted cells, but more studies are needed to prove this point. Low-level Cr2 reporter gene expression was also noted in dentate gyrus granule neurons, and very low levels of $\mathrm{Cr} 2$ transcripts were detected in primary astrocytes (Fig. 2D). CR2 expression had previously been documented in human glioma cells and fetal astrocytes (Gasque et al., 1996), but its expression in mice seems much lower.

We do not know how Cr2 deficiency causes the observed increase in neurogenesis and which splice form of the $\mathrm{Cr} 2$ gene mediates this effect. Mouse CD35 and CR2 are spliced from the same gene, and no conditions have been reported to favor splicing of one or the other product, suggesting both isoforms are expressed on NPCs similar to their coexpression on B-cells (Ja- 
cobson and Weis, 2008). Furthermore, it is predicted that mouse CR2 ligands would also bind to mouse CD35, making it difficult to exclude a role for CD35 in the observed effects (Molina et al., 1994). Additional studies will also be necessary to address whether CR2 on NPCs forms a similar signaling complex as the one found in B-cells with CD19, CD81, and CD225. Notably, all three genes seem to be expressed in NPCs (supplemental Fig. S1, available at www.jneurosci.org as supplemental material).

Based on our results in CR2/CD35-deficient mice, physiological levels of endogenous ligands may function to control basal neurogenesis, whereas increased levels of complement C3d or IFN- $\alpha$ after injury may lead to detrimental inhibition of neurogenesis. Human CR2 is the main receptor for C3d; it is also a receptor for IFN- $\alpha$ (although IFN- $\alpha$ signals through classical IFN- $\alpha$ receptors as well), CD23, and the Epstein-Barr virus envelope protein gp350 (Asokan et al., 2006). Interestingly, basal neurogenesis in the dentate gyrus was significantly reduced not only in C3aR knock-out mice but also in C3 knock-out mice (Rahpeymai et al., 2006), which cannot generate the $\mathrm{C} 3$ cleavage product C3a. Because C3d is also derived from C3, we would expect neurogenesis to increase in $\mathrm{C} 3$ knock-out mice if $\mathrm{C} 3 \mathrm{~d}$ signaling was actively suppressing neurogenesis via $\mathrm{Cr} 2$. We therefore think $\mathrm{C} 3 \mathrm{~d}$ is not responsible for suppressing neurogenesis via $\mathrm{Cr} 2 \mathrm{un}$ der physiological conditions. Nevertheless, C3d appears to be sufficient to reduce the number of immature neuroblasts in vivo (Fig. 7) and may exert such a function after CNS injury. We think it is more likely that CR2 ligands exert their effect by reducing proliferation of neuroblasts rather than by increasing apoptosis because we were unable to detect an increase in activated caspase staining in vivo, although the methods successfully detected alcohol-induced cell death (data not shown). With respect to IFN- $\alpha$, at least 13 functional subtypes have been described in humans (Theofilopoulos et al., 2005), and it is unclear whether they are constitutively produced at levels that might trigger CR2 signaling in NPCs in the normal brain and whether they differ in their affinity for CR2. Even without knowing the key endogenous ligand, therapeutic inhibition of CR2 signaling may promote basal neurogenesis in aging or restore neurogenesis in a number of inflammatory conditions where C3d or IFN- $\alpha$ are elevated and neurogenesis is reduced.

Adult hippocampal neurogenesis is being linked ever more strongly to the formation of specific new memories in rodents (Dupret et al., 2008; Zhang et al., 2008), and it is possible that neurogenesis in the human hippocampus may have a similar role (Leuner et al., 2006; Zhao et al., 2008). Although this issue is far from being settled, our findings may shed new light on an intriguing association of increased levels of C3d or IFN- $\alpha$ with memory problems or neuropsychiatric conditions in several human diseases. For example, C3d levels are increased in human immunodeficiency virus (HIV) (Fust et al., 1991), and increased levels of IFN- $\alpha$ in the CSF have been linked with HIV dementia (Rho et al., 1995). Similarly, C3d (Rother et al., 1993) and IFN- $\alpha$ (Harrison and Ravdin, 2002; Schmidt and Ouyang, 2004) levels are increased in autoimmune diseases such as systemic lupus erythematosus, which frequently presents with cognitive impairment. Perhaps the strongest evidence for a possible link between IFN- $\alpha$ and cognition comes from patients treated with recombinant IFN- $\alpha$ as part of a therapy for hepatitis $\mathrm{C}$ virus infection or cancer (Pavol et al., 1995; Scheibel et al., 2004; Hilsabeck et al., 2005). At least one-third of patients have been reported to develop depression or cognitive deficits linked to the treatment, and normal function is regained after treatment is discontinued. Consistent with these observations in humans, adult rats treated with IFN- $\alpha$ showed depression-like symptoms and reduced cell proliferation (BrdU incorporation) in the dentate gyrus (Kaneko et al., 2006). Although these authors had no mechanistic explanation of their findings, our study suggests that the observed effects of IFN- $\alpha$ in rats and possibly in humans could be mediated through CR2 expressed on NPCs. Together with published studies, our findings support a scenario in which abnormal CR2 signaling in certain viral infections and autoimmune disorders inhibits neurogenesis and, as a result, leads to depressive symptoms and cognitive impairments.

\section{References}

Anderson MF, Aberg MA, Nilsson M, Eriksson PS (2002) Insulin-like growth factor-I and neurogenesis in the adult mammalian brain. Brain Res Dev Brain Res 134:115-122.

Asokan R, Hua J, Young KA, Gould HJ, Hannan JP, Kraus DM, Szakonyi G, Grundy GJ, Chen XS, Crow MK, Holers VM (2006) Characterization of human complement receptor type 2 (CR2/CD21) as a receptor for IFNalpha: a potential role in systemic lupus erythematosus. J Immunol 177:383-394.

Bauer S, Patterson PH (2006) Leukemia inhibitory factor promotes neural stem cell self-renewal in the adult brain. J Neurosci 26:12089-12099.

Belteki G, Haigh J, Kabacs N, Haigh K, Sison K, Costantini F, Whitsett J, Quaggin SE, Nagy A (2005) Conditional and inducible transgene expression in mice through the combinatorial use of Cre-mediated recombination and tetracycline induction. Nucleic Acids Res 33:e51.

Buckwalter MS, Yamane M, Coleman BS, Ormerod BK, Chin JT, Palmer T, Wyss-Coray T (2006) Chronically increased transforming growth factor-betal strongly inhibits hippocampal neurogenesis in aged mice. Am J Pathol 169:154-164.

Carroll MC (2004) The complement system in B cell regulation. Mol Immunol 41:141-146.

Coxon A, Rieu P, Barkalow FJ, Askari S, Sharpe AH, von Andrian UH, Arnaout MA, Mayadas TN (1996) A novel role for the b2 integrin CD11b/ CD18 in neutrophil apoptosis: a homeostatic mechanism in inflammation. Immunity 5:653-666.

D'Ambrosio AL, Pinsky DJ, Connolly ES (2001) The role of the complement cascade in ischemia/reperfusion injury: implications for neuroprotection. Mol Med 7:367-382.

Dash PK, Mach SA, Moore AN (2001) Enhanced neurogenesis in the rodent hippocampus following traumatic brain injury. J Neurosci Res 63:313-319.

Dupret D, Revest JM, Koehl M, Ichas F, De Giorgi F, Costet P, Abrous DN, Piazza PV (2008) Spatial relational memory requires hippocampal adult neurogenesis. PLoS One 3:e1959.

Ekdahl CT, Claasen JH, Bonde S, Kokaia Z, Lindvall O (2003) Inflammation is detrimental for neurogenesis in adult brain. Proc Natl Acad Sci U S A 100:13632-13637.

Fonseca MI, Zhou J, Botto M, Tenner AJ (2004) Absence of C1q leads to less neuropathology in transgenic mouse models of Alzheimer's disease. J Neurosci 24:6457-6465.

Fust G, Ujhelyi E, Hidvegi T, Paloczi K, Mihalik R, Hollan S, Nagy K, Kirschfink M (1991) The complement system in HIV disease. Immunol Invest 20:231-241.

Gasque P (2004) Complement: a unique innate immune sensor for danger signals. Mol Immunol 41:1089-1098.

Gasque P, Chan P, Mauger C, Schouft MT, Singhrao S, Dierich MP, Morgan BP, Fontaine M (1996) Identification and characterization of complement C3 receptors on human astrocytes. J Immunol 156:2247-2255.

Haines JL, Hauser MA, Schmidt S, Scott WK, Olson LM, Gallins P, Spencer KL, Kwan SY, Noureddine M, Gilbert JR, Schnetz-Boutaud N, Agarwal A, Postel EA, Pericak-Vance MA (2005) Complement factor $\mathrm{H}$ variant increases the risk of age-related macular degeneration. Science 308:419-421.

Harrison MJ, Ravdin LD (2002) Cognitive dysfunction in neuropsychiatric systemic lupus erythematosus. Curr Opin Rheumatol 14:510-514.

Hilsabeck RC, Hassanein TI, Ziegler EA, Carlson MD, Perry W (2005) Effect of interferon-alpha on cognitive functioning in patients with chronic hepatitis C. J Int Neuropsychol Soc 11:16-22.

Holers VM (1996) Complement. In: Clinical immunology principles and practice (Rich RR, ed), pp 363-391. St. Louis: Mosby-Year Book. 
Hsiao FC, Lin M, Tai A, Chen G, Huber BT (2006) Cutting edge: EpsteinBarr virus transactivates the HERV-K18 superantigen by docking to the human complement receptor 2 (CD21) on primary B cells. J Immunol 177:2056-2060

Iosif RE, Ekdahl CT, Ahlenius H, Pronk CJ, Bonde S, Kokaia Z, Jacobsen SE, Lindvall O (2006) Tumor necrosis factor receptor 1 is a negative regulator of progenitor proliferation in adult hippocampal neurogenesis. J Neurosci 26:9703-9712.

Jacobson AC, Weis JH (2008) Comparative functional evolution of human and mouse CR1 and CR2. J Immunol 181:2953-2959.

Jin K, Minami M, Xie L, Sun Y, Mao XO, Wang Y, Simon RP, Greenberg DA (2004) Ischemia-induced neurogenesis is preserved but reduced in the aged rodent brain. Aging Cell 3:373-377.

Kaneko N, Kudo K, Mabuchi T, Takemoto K, Fujimaki K, Wati H, Iguchi H, Tezuka H, Kanba S (2006) Suppression of cell proliferation by interferon-alpha through interleukin-1 production in adult rat dentate gyrus. Neuropsychopharmacology 31:2619-2626.

Klein RJ, Zeiss C, Chew EY, Tsai JY, Sackler RS, Haynes C, Henning AK, SanGiovanni JP, Mane SM, Mayne ST, Bracken MB, Ferris FL, Ott J, Barnstable C, Hoh J (2005) Complement factor H polymorphism in age-related macular degeneration. Science 308:385-389.

Koo JW, Duman RS (2008) IL-1beta is an essential mediator of the antineurogenic and anhedonic effects of stress. Proc Natl Acad Sci U S A 105:751-756.

Kraus M, Alimzhanov MB, Rajewsky N, Rajewsky K (2004) Survival of resting mature B lymphocytes depends on BCR signaling via the Igalpha/beta heterodimer. Cell 117:787-800.

Kuhn HG, Dickinson-Anson H, Gage FH (1996) Neurogenesis in the dentate gyrus of the adult rat: age-related decrease of neuronal progenitor proliferation. J Neurosci 16:2027-2033.

Lambert JC, Heath S, Even G, Campion D, Sleegers K, Hiltunen M, Combarros O, Zelenika D, Bullido MJ, Tavernier B, Letenneur L, Bettens K, Berr C, Pasquier F, Fiévet N, Barberger-Gateau P, Engelborghs S, De Deyn P, Mateo I, Franck A, et al. (2009) Genome-wide association study identifies variants at CLU and CR1 associated with Alzheimer's disease. Nat Genet 41:1094-1099.

Leuner B, Gould E, Shors TJ (2006) Is there a link between adult neurogenesis and learning? Hippocampus 16:216-224.

Maier M, Peng Y, Jiang L, Seabrook TJ, Carroll MC, Lemere CA (2008) Complement $\mathrm{C} 3$ deficiency leads to accelerated amyloid beta plaque deposition and neurodegeneration and modulation of the microglia/macrophage phenotype in amyloid precursor protein transgenic mice. J Neurosci 28:6333-6341.

Martin DR, Yuryev A, Kalli KR, Fearon DT, Ahearn JM (1991) Determination of the structural basis for selective binding of Epstein-Barr virus to human complement receptor type 2. J Exp Med 174:1299-1311.

Molina H, Brenner C, Jacobi S, Gorka J, Carel JC, Kinoshita T, Holers VM (1991) Analysis of Epstein-Barr virus-binding sites on complement receptor 2 (CR2/CD21) using human-mouse chimeras and peptides. At least two distinct sites are necessary for ligand-receptor interaction. J Biol Chem 266:12173-12179.

Molina H, Kinoshita T, Webster CB, Holers VM (1994) Analysis of C3b/ $\mathrm{C} 3 \mathrm{~d}$ binding sites and factor I cofactor regions within mouse complement receptors 1 and 2. J Immunol 153:789-795.

Molina H, Holers VM, Li B, Fang Y-F, Mariathasan S, Goellner J, StraussSchoenberger J, Karr RW, Chaplin DD (1996) Markedly impaired humoral immune response in mice deficient in complement receptors 1 and 2. Proc Natl Acad Sci U S A 93:3357-3361.

Monje ML, Mizumatsu S, Fike JR, Palmer TD (2002) Irradiation induces neural precursor-cell dysfunction. Nat Med 8:955-962.
Monje ML, Toda H, Palmer TD (2003) Inflammatory blockade restores adult hippocampal neurogenesis. Science 302:1760-1765.

Muzumdar MD, Tasic B, Miyamichi K, Li L, Luo L (2007) A global doublefluorescent Cre reporter mouse. Genesis 45:593-605.

Pavol MA, Meyers CA, Rexer JL, Valentine AD, Mattis PJ, Talpaz M (1995) Pattern of neurobehavioral deficits associated with interferon alfa therapy for leukemia. Neurology 45:947-950.

Rahpeymai Y, Hietala MA, Wilhelmsson U, Fotheringham A, Davies I, Nilsson AK, Zwirner J, Wetsel RA, Gerard C, Pekny M, Pekna M (2006) Complement: a novel factor in basal and ischemia-induced neurogenesis. EMBO J 25:1364-1374.

Reynolds BA, Rietze RL (2005) Neural stem cells and neurospheres-reevaluating the relationship. Nat Methods 2:333-336.

Rho MB, Wesselingh S, Glass JD, McArthur JC, Choi S, Griffin J, Tyor WR (1995) A potential role for interferon-alpha in the pathogenesis of HIVassociated dementia. Brain Behav Immun 9:366-377.

Rother E, Lang B, Coldewey R, Hartung K, Peter HH (1993) Complement split product $\mathrm{C} 3 \mathrm{~d}$ as an indicator of disease activity in systemic lupus erythematosus. Clin Rheumatol 12:31-35.

Sahu A, Lambris J (2001) Structure and biology of complement protein C3, a connecting link between innate and acquired immunity. Immunol Rev 180:35-48.

Scheibel RS, Valentine AD, O’Brien S, Meyers CA (2004) Cognitive dysfunction and depression during treatment with interferon-alpha and chemotherapy. J Neuropsychiatry Clin Neurosci 16:185-191.

Schmidt KN, Ouyang W (2004) Targeting interferon-alpha: a promising approach for systemic lupus erythematosus therapy. Lupus 13:348-352.

Shetty AK, Rao MS, Hattiangady B, Zaman V, Shetty GA (2004) Hippocampal neurotrophin levels after injury: relationship to the age of the hippocampus at the time of injury. J Neurosci Res 78:520-532.

Shimazaki T, Shingo T, Weiss S (2001) The ciliary neurotrophic factor/leukemia inhibitory factor/gp130 receptor complex operates in the maintenance of mammalian forebrain neural stem cells. J Neurosci 21:7642-7653.

Stevens B, Allen NJ, Vazquez LE, Howell GR, Christopherson KS, Nouri N, Micheva KD, Mehalow AK, Huberman AD, Stafford B, Sher A, Litke AM, Lambris JD, Smith SJ, John SW, Barres BA (2007) The classical complement cascade mediates CNS synapse elimination. Cell 131:1164-1178.

Theofilopoulos AN, Baccala R, Beutler B, Kono DH (2005) Type I interferons (alpha/beta) in immunity and autoimmunity. Annu Rev Immunol 23:307-336.

Tolnay M, Tsokos GC (1998) Complement receptor 2 in the regulation of the immune response. Clin Immunol Immunopathol 88:123-132.

Wachs FP, Winner B, Couillard-Despres S, Schiller T, Aigner R, Winkler J, Bogdahn U, Aigner L (2006) Transforming growth factor-betal is a negative modulator of adult neurogenesis. J Neuropathol Exp Neurol 65:358-370.

Wyss-Coray T, Yan F, Lin AH, Lambris JD, Alexander JJ, Quigg RJ, Masliah E (2002) Prominent neurodegeneration and increased plaque formation in complement-inhibited Alzheimer's mice. Proc Natl Acad Sci U S A 99:10837-10842.

Yagita Y, Kitagawa K, Ohtsuki T, Takasawa K, Miyata T, Okano H, Hori M, Matsumoto M (2001) Neurogenesis by progenitor cells in the ischemic adult rat hippocampus. Stroke 32:1890-1896.

Zhang CL, Zou Y, He W, Gage FH, Evans RM (2008) A role for adult TLXpositive neural stem cells in learning and behaviour. Nature 451: $1004-1007$

Zhao C, Deng W, Gage FH (2008) Mechanisms and functional implications of adult neurogenesis. Cell 132:645-660. 